\title{
Equilibrium
}

Quarterly Journal of Economics and Economic Policy

VOLUME 8 ISSUE 4, 2013

ISSN 1689-765X, (Online) ISSN 2353-3293

http://www.equilibrium.umk.pl/

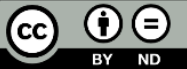

Cieślik A., Michałek J., Michałek A. (2013), The Impact of the Common Currency on Exports of New EMU members: Firm-level Evidence for Slovenia and Slovakia, "Equilibrium. Quarterly Journal of Economics and Economic Policy", Volume 8, Issue 4, pp. 7-23, DOI: http://dx.doi.org/10.12775/EQUIL.2013.024

\author{
Andrzej Cieślik, Jan Michałek, Anna Michałek* \\ University of Warsaw, Poland
}

\section{The Impact of the Common Currency on Exports of New EMU Members: Firm-level Evidence for Slovenia and Slovakia}

JEL Classification: $F 12, F 14, F 33$

Keywords: common currency, export, new EMU members

Abstract: There are many studies aiming at estimation of aggregate trade effects of the euro adoption by the old EU countries, which are based on the augmented gravity model. In contrast to the existing literature, we investigate whether the adoption of the common currency increases the export activity of individual firms. In particular, we refer to the new strand in the trade theory literature, based on the Melitz (2003) model, in which export performance depends on labor productivity and costs of exporting. There are already many empirical studies, based on firm level data, showing the relevance of the Melitz (2003) model. Most of those studies demonstrate that export performance positively depends on firms' characteristics such as labor productivity, spending on $R \& D$, age of the firm, the stock of human capital or propensity to innovate, but they do not take into account the impact of the common currency on the cost of exporting. There are only few studies analyzing trade implications of euro adoption for firms' exports of "old EU" members. In our empirical paper we use the firm level data basis set up by the EBRD and the World Bank for Central and Eastern European Countries. Using the probit model, we analyze

(C) Copyright Institute of Economic Research \& Polish Economic Society Branch in Torun

Date of submission: February 28, 2013; date of acceptance: June 17, 2013

*Contact: michalek@wne.uw.edu.pl, University of Warsaw, ul. Długa 44/50, 00-241

Warszawa, Poland

${ }^{* *}$ This research is a part of a broader project financed by the Economic Institute of the National Bank of Poland. 
whether the accession of Slovenia and Slovakia to the Eurozone did increase the firms' propensity to export in those countries.

\section{Introduction}

The impact of the adoption of a common currency on international trade flows has been one of the hotly debated issues in international economics. It has been frequently argued that the reduction in transaction costs due the elimination of the exchange rate risk should stimulate exports of existing firms and encourage non-exporters that previously limited their operations to their domestic markets to start exporting (Baldwin et al. 2005). This effect is perceived to be especially important for countries where forward foreign exchange markets are not very well-developed. Moreover, a reduction of the transaction cost is argued to be important for countries that are characterized by the strong concentration of their trade with one large trading partner or a group of countries that share a common currency. This is the case for many Central and Eastern European (CEE) countries for which Germany is the main trading partner, and more than 50 per cent of their trade takes place with the members of the Eurozone. This issue has become even more important after the Eastern enlargement of the EU in 2004 and 2007.

The new EU member states are obliged to eventually join the Eurozone, however the final date has not been set for many of them. The accession the Eurozone requires the fulfillment of the Maastricht convergence criteria. One of them is related to the accession to the exchange rate mechanism (ERM II), with the aim of reducing the exchange rate variability. Following the first wave of the EU enlargement to the East, Estonia, Lithuania and Slovenia joined the ERM II already in June 2004, Cyprus, Latvia and Malta in May 2005, while Slovakia in November 2005.

Slovenia was the first country to join the Eurozone in January 2007. Cyprus and Malta joined the Eurozone in January 2008, Slovakia in January 2009, and Estonia in January 2011. whereas Latvia is expected to do it in 2014. Other countries from Central and Eastern Europe such as Bulgaria, the Czech Republic, Hungary, Poland and Romania, who joined the EU despite their declarations to adopt the euro, have not joined the ERM II so far. ${ }^{1}$

According to many empirical studies, the trade flows among the old members of the EMU have grown on average by $5-10 \%$ due to the use of a common currency and there was also an increase in trade with the nonmember states (Baldwin 2006). However, these studies did not take into account the latest EMU enlargements and the impact of 2008-2009 world

\footnotetext{
${ }^{1}$ Bulgaria, although it did not officially enter the ERM II, pegged its currency to the euro since its creation in 1999 (before the Bulgarian lev was pegged to the German mark).
} 
economic crisis. Moreover, the empirical evidence on the trade consequences of the euro adoption in the new EU members states is still scarce.

The main aim of this paper is to evaluate the ex post effects of new EU member countries' accession to the European Economic and Monetary Union (EMU) on the export performance of their firms. In our study, we focus on two Central European countries: Slovakia and Slovenia, which are new EU member countries that have already adopted the euro. Unfortunately, we cannot extend our analysis to include Estonia, due to the lack of data covering the period after the Eurozone accession.

To evaluate these effects, we use probit estimation, based on the Melitz (2003) model and firm-level data. This study will help in understanding whether and by how much the adoption of the euro contributed to the of firm's exports. In particular, two different effects can be distinguished and analyzed. First, the extensive margin, which means a small positive differential effect on trade through an increase in the number of products exported. Second, an intensive margin means a larger positive differential effect on average value of exports per firm and/or per product (Fontagne et al. 2009).

The structure of this paper is as follows: in the next section we survey the literature on the impact of the euro adoption with the special focus on the Central and European countries. Then, we describe the analytical framework and discuss data sources. Finally, we first present estimation results on the ex post impact of the euro adoption on firms' export performance in Slovakia and Slovenia that have already adopted the common currency. The last section summarizes and concludes.

\section{Literature Review}

Trade effects of the adoption of a common currency can be studied in a number of ways. Traditionally, the trade economists used to study empirically aggregate trade flows on the basis of augmented gravity equations derived from the neoclassical and new trade theories. In this approach binary variables, describing the participation in the exchange rate stabilization regimes and the membership in the monetary union are usually used. Additionally, some measures of exchange rate volatility can be included in the estimating equations.

The first attempts to study the trade implications of the adoption of the common currency were based on the gravity models estimated for the aggregate trade flows. The widely cited studies by Rose $(2000,2001)$ identified two main effects of the adoption of a common currency: the effects associated with the elimination of the exchange rate volatility, and the pure monetary effect associated with the use of a single currency. His early studies yielded 
surprising results, suggesting that the participation in the monetary union may increase trade between its member countries several-fold.

Since then, a number of follow-up studies based on the gravity model have emerged. Many authors have suggested various reasons for the overestimation of trade effects associated with the adoption of a common currency such as a sample selection bias or the endogeneity of the monetary union. ${ }^{2}$ The early extensive survey of the empirical studies on the potential trade effects of the participation in the monetary union for the old EU countries has been provided by Baldwin (2006). A more recent survey of the empirical literature based on the gravity model, including the forecasts of trade effects of the euro adoption in the new EU member countries, can be found in Cieślik, Michałek and Mycielski (2012a,b).

The literature dealing with the ex post evaluation of the aggregate trade effects of euro adoption in the new EU member states is much less abundant. The existing literature for these countries concentrated so far on the fulfillment of the Maastricht criteria for the euro adoption, growth and business cycle synchronization. The examples include studies by Fidrmuc and Korhonen (2006), De Grauwe and Schnabl (2008), Frankel (2008), Feuerstein and Grimm (2007), and Sivak R. (2011). However, the formal ex post econometric evidence on the consequences of the euro adoption in the new EU members states for their aggregate trade flows is still scarce.

In particular, Aristovnik and Meze (2009) used a time series approach to study the ex post effect of the EMU creation for Slovenian trade. They argued that the trade benefits of the entry of new countries into the EMU would thus not be the same as the benefits of the initial formation of the EMU in the nineties. They validated their claim using the case-study evidence for Slovenia. Their regression analysis of time series showed that there had been a positive effect on Slovenia's exports into and a negative effect on its imports from the Eurozone precisely at the time of the creation of the EMU in 1999. However, in their study they did not investigate the ex post effects themselves of 2006 Slovenia accession to the Eurozone.

This issue was taken up in the empirical study by Cieślik, Michałek and Mycielski $(2012 b, c)$ who studied the implications of accession of two new Central European countries: Slovenia and Slovakia to the already existing and functioning EMU. The authors employed a gravity model that controlled for an extended set of trade theory and policy variables. Trade theory variables included both the country size and factor proportion variables.

\footnotetext{
${ }^{2}$ For example, endogeneity can be associated with central bank policies and colonial ties. In particular, exchange rate volatility may not be exogenous if central banks want to decrease the range of exchange rate fluctuations with respect to the currencies of their main trading partners. The main trading partners for developing countries are often former colonizers with respect to which former colonies stabilize their exchange rates.
} 
Trade policy variables included the membership in GATT/WTO, CEFTA, OECD, EU and Europe Agreements. The gravity model was estimated using the panel data approach on a sample of CEE countries trading with the rest of the world during the period 1992-2009 using the fixed effects, random effects and Hausman-Taylor estimators. According to their results, elimination of exchange rate volatility resulted in trade expansion for the CEE countries, but the accession to the Eurozone did not have any significant effects on exports of Slovakia and Slovenia. ${ }^{3}$ Thus, these results are in contrast to the results obtained for the old EU member states which show that the introduction of the euro had a modest but positive impact on the value of aggregate trade flows inside the euro area.

However, it can be argued that the results are based on the gravity model and aggregate trade data mask important microeconomic gains. In particular, two types of microeconomic gains that may arise even though aggregate trade flows do not change can be distinguished. First, the euro may increase the availability of differentiated varieties of both final and intermediate products. In addition to this, it may also help existing exporters to increase the number of products exported and the number of destinations served. The aggregate exports may not change if richer product variety coincides with an offsetting reduction in average shipments per product. Second, the value of aggregate exports may be affected by the increased competition resulting in the compression of prices. Enhanced transparency and lower transaction costs associated with the introduction of the euro may lead to a fall in markups and prices across the euro area. With no major change in relative prices, aggregate trade flows should not change much either.

The new approach to studying the trade effects of the euro is based on the latest strand in the trade theory literature. This alternative approach is based on the Melitz (2003) model. In contrast to the previous literature, i.e. the Krugman (1980) model, which assumed that firms are symmetric, this new literature focuses on firms' heterogeneity in terms of productivity and export performance. The Melitz (2003) model implies important microeconomic effects of reduction in transaction costs. Namely, this reduction should lead to significant changes within sectors: growth of the most efficient firms, a richer variety of goods, tougher competition (i.e., smaller mark-ups), and consequently, exit of the least efficient firms.

\footnotetext{
${ }^{3}$ These results do not seem surprising given the fact that some of the studies for the old EU member states do not find any positive trade effect of the Eurozone creation. For example, Berger and Nitsch (2008) argued that the euro's impact on trade disappears if the positive trend in the institutional integration is controlled for.
} 
The Melitz (2003) model can be used to study a whole range of various issues related to the reduction of transaction costs. In particular, it can be used to analyze the effects of the adoption of the common currency on firms' export performance. In the light of this model it might be argued that the adoption of the common currency lowers trade costs and can positively affect the firm's export performance.

There are only few empirical studies that investigate the microeconomic trade effects of the accession to the Eurozone for the old EU member states (EU-15), and the empirical evidence for the new EU member states is virtually non-existent. In particular, Fontagne et al. (2009) analyze the implications of the euro adoption for Belgium and France using firm-level data for the period of 1998-2003. They exploit firm-level export databases at the product level. For each exporter, they have information on the value of exports detailed by product $\mathrm{CN} 8$ category (10,000 product categories) which allows them to identify the destination market. On this basis, they compute the number of exporters on each market, the average number of products exported by firm on each market, and the average value of exports by product. Specifically, they compare the evolution of the trade margins to euroarea destinations with the evolution of the trade margins to non-euro area destinations for Belgium and France.

In the case of France, the number of firms exporting to euro-area destinations decreased, while the average number of products exported per firm and the average number of destinations per variety increased. In the case of Belgium, the number of firms, the number of products exported per firm, and the number of destinations per variety increased. In the case of both countries, the intensive margin increased for these destinations. Hence, since the introduction of the euro, fewer French firms export more products to more destination markets within the euro area, while more Belgian firms export more products to more destinations within the euro area.

A similar pattern was observed for non-euro area EU destinations. However, contrary to what was observed for euro-area destinations, there was no variation in the number of countries served per variety within the non-euro area EU region. This was due to the fact that this region consists of three countries only. Hence, since the introduction of the euro, changes observed within the European Union did not differ much for destinations in the euro area and destinations outside the euro area.

The exports of French firms to non-euro area Europe and non-euro area world destinations behaved differently from exports to the EU destinations. ${ }^{4}$ The number of exported products decreased, while there was a small increase in the number of exporting firms and in the number of destinations

\footnotetext{
${ }^{4}$ The study was conducted for the period preceding the Eastern enlargements and the CEE countries were not at that time the EU members.
} 
per variety. Unlike France, in the case of Belgium a decrease in the number of exporters, especially to destinations outside Europe was reported. Thus, after the introduction of the euro, fewer Belgian firms export more products to more destinations outside the EU. More French firms export fewer products to more destinations outside the EU.

Therefore, since the introduction of the euro, changes in the total value of euro-area exports were driven mostly by the extensive margin (the number of exporting firms, products exported and countries served) in the case of euro-area destinations and by the intensive margin (the average value of exports per product and exporter across destinations) in the case of nonEuropean destinations.

Fontagne et al. (2009) also suggested that there have been changes in the geographical pattern in the firms' exports resulting from the exchange rate adjustments. Namely, real appreciation of the euro reduced French exports to old EU15 countries through the average value of exports per product and exporter, while the number of exporters, products exported and countries served was also affected when all destination countries were considered.

Another aspect of firms' reaction to the exchange rate adjustment was analyzed in the study by Berman et al. (2009). They also focused on export performance of French firms during the period of 1995-2005. Their results showed that high productivity firms reacted to a depreciation by increasing their export price, rather than their export volume. The reverse was true for low productivity firms. The extensive margin response to exchange rate changes was modest at the aggregate level because firms that enter, following a depreciation, are smaller relative to existing firms.

In the context of Central and Eastern European countries, according to the best of our knowledge, it seems that there are no formal empirical studies based on firm-level data. There are only some studies devoted to evaluation of ex ante effects of the accession to the Eurozone on trade flows based on surveys of the perception of firms. For example, Klučka et al. (2009), surveyed firms and asked whether the accession to the Eurozone would eliminate the transaction costs, the exchange rate risk, and will lead to the simplification of doing business with partners in the Eurozone which should result in trade expansion. This perception was especially pronounced among big enterprises in Slovakia. Moreover, small and medium size enterprises stressed the chances for new market acquisition. At the same time, those firms expected an increase in competitive pressure from foreign competitors. But the authors did not estimate trade effects of the accession to the Eurozone. 


\section{Empirical Methodology and Data Description}

The new strand of trade theory provides a useful tool for the analysis of trade performance in response to the reduction of transaction costs. In particular, we refer to the Melitz (2003) model and focus on the effect of increased participation of non-exporters in international markets which is an equivalent of studying the extensive margin effects.

In the Melitz (2003) model, productivity differences among firms are the key variable explaining the firm's ability to enter export markets. In this model, a company's productivity is exogenously given and each firm has to pay a fixed cost when entering the domestic and foreign markets. The model predicts that the most productive firms with the lowest marginal costs can pay the fixed cost of entry and become an exporter. On one hand, a fall in the importing costs will force the least productive firms to exit the domestic market and reallocate market shares from these firms to the more productive ones. As a result, the average level of productivity within the sector will increase. On the other hand, a reduction in the exporting costs will reduce the threshold level of productivity that firms need to achieve in order to export, and consequently the non-exporters with the highest productivity will be able to enter the foreign market.

The importance of the company's productivity for exporting has been confirmed by the EFIGE (2010) report. In this report it has been demonstrated that firm export performance in seven EU countries depends on labour productivity and other firm characteristics. Unfortunately, these studies did not include the countries of Central and Eastern Europe with the exception of Hungary. Similar studies for the Visegrad countries (i.e. the Czech Republic, Slovakia, Hungary and Poland), and separately for Poland were conducted by Cieślik, Michałek and Michałek (2012a,b). Their analysis showed that the productivity of the labour force was positively related to the probability of exporting. In addition, in their empirical studies, other factors such as spending on R\&D, size of the firm, internationalization of the firm, and the stock of the human capital may affect export business decisions were examined. These results were similar to the results presented in the EFIGE (2010) report.

However, in all the aforementioned studies, the authors did not control for the participation in the Eurozone. Therefore, in this section we use the probit model to study the relationship between exporting and the common currency, having controlled for firms' characteristics and the EU membership. Based on the previous theoretical literature, we develop an empirical model to investigate how the reduction in transaction costs associated with entering markets in other countries that share the common currency affects 
the probability of exporting. This probability is modeled as a linear function of firm, industry and country characteristics.

Let $Y_{i}{ }^{*}$ be our dependent variable indicating the export status of the firm i. This variable is a latent variable. This means that instead of observing the volume of exports, we observe only a binary variable $Y_{i}$ indicating the sign of $Y_{i}^{*}$. Our dependent variable follows a binary distribution and takes the value 1 when the firm exports and 0 otherwise:

$$
Y_{t}= \begin{cases}1 & \text { if } Y_{i}^{*}>0 \\ 0 & \text { if } Y_{i}^{*}=0\end{cases}
$$

Moreover, we assume that $Y_{i}^{*}=X_{i} \theta+\varepsilon_{i}$, where $X_{i}$ is a vector of explanatory variables affecting exports, $\theta$ is the vector of parameters on these variables that needs to be estimated and $\varepsilon_{i}$ is an error term which is assumed to be normally distributed with a zero mean. Hence, the probability that a firm exports can be written as:

$$
\operatorname{Pr}\left(Y_{i}=1 \mid X_{i}\right)=\Phi\left(\beta+X_{i} \theta\right)
$$

Our analysis is based on the EBRD-World Bank Business Environment and Enterprise Performance Survey (BEEPS) data collected by the World Bank and the European Bank for Reconstruction and Development for the post-communist countries located in Europe and Central Asia $(E C A)$ and Turkey. The surveys covered the manufacturing and services sectors and are representative of the variety of firms according to the sector and the location within each country. The data was collected for the years 2002, 2005, 2009 and 2010. In all countries where a reliable sample frame was available (except Albania), the sample was selected using stratified random sampling. ${ }^{5}$ However, only a small proportion of firms was sampled every year. ${ }^{6}$

Our study focuses on the Central and Eastern European countries and Turkey. We assume that export activity occurs when at least one percent of sales revenue comes from sales made abroad. In Table 1, we present the export propensity of firms from the Central and Eastern European countries, treating Turkey as a benchmark - a market economy from the region free of a communist past.

5 The sampling methodology is explained in the Sampling Manual (available at http://www.enterprisesurveys.org/Methodology/).

${ }^{6}$ This means that the application of panel data analysis is not possible. Therefore, we used the standard probit procedure on the pooled dataset without controlling for individual firm effects. 
Table 1. A comparison of the propensity to export among the firms Central and Eastern European countries including Turkey

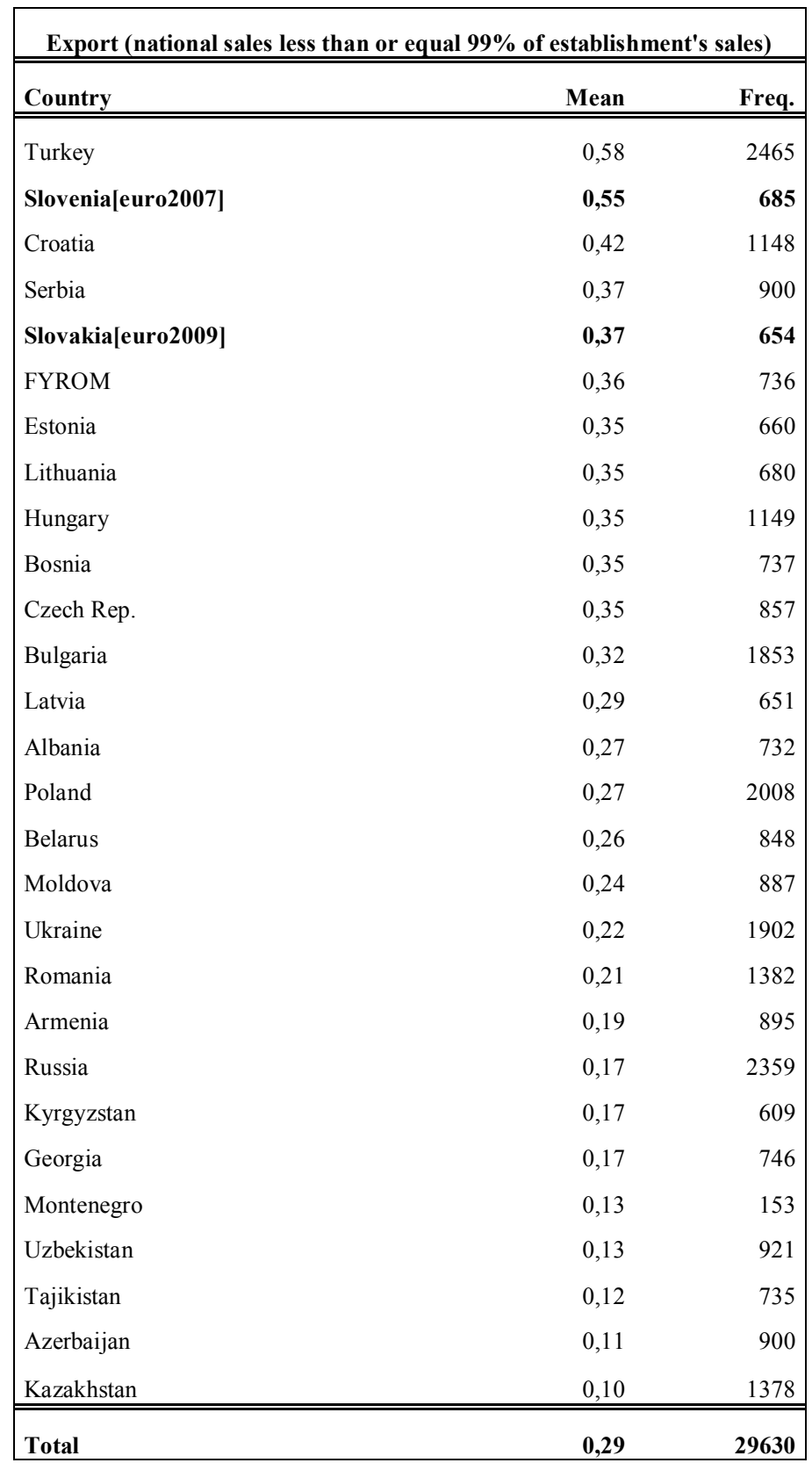

Note: Countries that adopted euro till 2010 are marked bold.

Source: own calculations based on the BEEPS data. 
However, the great degree of heterogeneity in export performance, even among the CEE countries, cannot only be explained by the standard country characteristics that are usually stressed by the traditional trade theory. Therefore, it is also important to study the role of the common currency and the EU membership in determining export performance, together with firm characteristics, specifically for the new trade theory.

The probability of exporting for analyzed CEE firms is dependent on a firm, a sector and a country's characteristics. The firm and sector characteristics are based on survey questions regarding the individual characteristics of the firm, sector of activity, legal and economic status, characteristics of managers and the size of the firm, economic performance and key characteristics of the reviewed firms, as well as stakeholders. The sample used in our econometric analysis includes cross-section data for almost six thousand observations for firms located in the CEE countries for which explanatory variables were available in all analyzed years. In Table 2, we present firm characteristics used in our study.

Table 2. Explanatory variables: Firm characteristics

\begin{tabular}{|l|l|l|}
\hline \multicolumn{1}{|c|}{ Variable Name } & \multicolumn{1}{|c|}{ BEEP input Name } & \multicolumn{1}{c|}{ Description } \\
\hline lprod & $\begin{array}{l}\text { lprod=log}(\operatorname{lprod}) \\
\text { prod=exchange rate* }(\mathrm{d} 2 / 11)\end{array}$ & $\begin{array}{l}\text { Logarithm of productivity expressed as total } \\
\text { amount of annual sales per full time employ- } \\
\text { ee. } \\
\text { The annual sales are converted from local } \\
\text { currencies to USD. }\end{array}$ \\
\hline luniv & luniv $=\log (\mathrm{ECAq} 69)$ & $\begin{array}{l}\text { Logarithm of } \% \text { employees at end of fiscal } \\
\text { year with a university degree. }\end{array}$ \\
\hline 1RaD & $\begin{array}{l}\mathrm{RaD}=(\mathrm{ECAo} / \mathrm{d} 2) * 100 \\
\mathrm{RaD}=\log (\mathrm{RaD})\end{array}$ & $\begin{array}{l}\text { Logarithm of } \% \text { of total annual sales spent on } \\
\text { research and development. }\end{array}$ \\
\hline foreign_cap & $\mathrm{b} 2 \mathrm{~b}$ & $\begin{array}{l}\text { Shares in capital of private foreign individu- } \\
\text { als, companies or organizations. }\end{array}$ \\
\hline medium & 11 & $\begin{array}{l}\text { Dummy variable for medium sized establish- } \\
\text { ments, takes value } 1 \text { of the establishment } \\
\text { hires between 20-99 employees and 0 other- } \\
\text { wise }\end{array}$ \\
\hline large & $\begin{array}{l}\text { Dummy variable for medium sized establish- } \\
\text { ments, takes value 1 of the establishment } \\
\text { hires between 100 employees or more and 0 } \\
\text { otherwise }\end{array}$ \\
\hline
\end{tabular}

Source: own elaboration. 
In addition to firm characteristics, we also included country characteristics such as the EMU and EU membership. The EMU membership variable is a dummy variable that takes value 1 when the country is the member of the Eurozone and zero otherwise. In the similar manner we define the EU membership variables which takes value 1 when the country is a member of the European Union. Finally, we have also controlled for individual time and sectoral effects.

\section{Estimation Results}

In Table 3, we present our estimation results. In column (1) we show the baseline results, while in columns (2) and (3) we also check the robustness of our results by controlling for sector specific effects. The key explanatory variables stressed by the Melitz (2003) model - productivity is expressed as the total amount of annual sales per full time employee (lprod). Other factors that may affect export activity include the level of innovation proxied by the $\mathrm{R} \& \mathrm{D}$ spending ( $\mathrm{RaD})$, the stock of human capital proxied by the percentage of employees with university degrees (luniv). In addition, we control for the foreign ownership (foreign_cap), and the size of the firm (medium and large).

Table 3. Estimation Results (standard errors in parentheses)

\begin{tabular}{|c|c|c|c|}
\cline { 2 - 4 } \multicolumn{1}{c|}{} & $(1)$ & $(2)$ & $(3)$ \\
\hline VARIABLES & Year Dummy & $\begin{array}{l}\text { Year and Sector Dum- } \\
\text { mies }\end{array}$ & $\begin{array}{l}\text { Year and Sector } \\
\text { Dummies }\end{array}$ \\
\hline lprod & $0.0536^{* * *}$ & $0.0537^{* * *}$ & $0.0537^{* * *}$ \\
\hline & $(0.00650)$ & $(0.00651)$ & $(0.00650)$ \\
\hline luniv & $0.00399^{* * *}$ & $0.00396^{* * *}$ & $0.00395^{* * *}$ \\
\hline & $(0.000603)$ & $(0.000605)$ & $(0.000604)$ \\
\hline IRaD & $0.0251^{* * *}$ & $0.0248^{* * *}$ & $0.0249^{* * *}$ \\
\hline Foreign_cap & $(0.00288)$ & $(0.00288)$ & $(0.00288)$ \\
\hline & $0.00768^{* * *}$ & $0.00770^{* * *}$ & $0.00771^{* * *}$ \\
\hline medium & $(0.000603)$ & $(0.000604)$ & $(0.000603)$ \\
\hline & $0.527^{* * *}$ & $0.526^{* * *}$ & $0.525^{* * *}$ \\
\hline large & $(0.0400)$ & $(0.0401)$ & $(0.0401)$ \\
\hline & $0.950^{* * *}$ & $0.958^{* * *}$ & $0.955^{* * *}$ \\
\hline & $(0.0459)$ & $(0.0460)$ & $(0.0460)$ \\
\hline
\end{tabular}


Table 3 continued

\begin{tabular}{|c|c|c|c|}
\hline & (1) & (2) & (3) \\
\hline VARIABLES & Year Dummy & $\begin{array}{l}\text { Year and Sector Dum- } \\
\text { mies }\end{array}$ & $\begin{array}{l}\text { Year and Sector } \\
\text { Dummies }\end{array}$ \\
\hline \multirow[t]{2}{*}{ EMU } & $0.880 * * *$ & $0.893^{* * *}$ & $0.866^{* * *}$ \\
\hline & $(0.247)$ & $(0.253)$ & $(0.251)$ \\
\hline \multirow[t]{2}{*}{ EU } & $0.446 * * *$ & $0.443 * * *$ & $0.445 * * *$ \\
\hline & $(0.0412)$ & $(0.0413)$ & $(0.0413)$ \\
\hline \multirow[t]{2}{*}{ d_2002 } & $-0.316^{* * *}$ & $-0.410 * * *$ & $-0.397 * * *$ \\
\hline & $(0.0670)$ & $(0.0762)$ & $(0.0708)$ \\
\hline \multirow[t]{2}{*}{ d_2005 } & $-0.366^{* * *}$ & $-0.461 * * *$ & $-0.449 * * *$ \\
\hline & $(0.0707)$ & $(0.0798)$ & $(0.0745)$ \\
\hline \multirow[t]{2}{*}{ d_2008 } & $0.503 * * *$ & $0.504 * * *$ & $0.497 * * *$ \\
\hline & $(0.103)$ & $(0.106)$ & $(0.104)$ \\
\hline \multirow[t]{2}{*}{ d_food } & & $-0.457 * * *$ & $-0.441 * * *$ \\
\hline & & $(0.125)$ & $(0.121)$ \\
\hline \multirow[t]{2}{*}{ d_textiles } & & -0.0829 & \\
\hline & & $(0.134)$ & \\
\hline \multirow[t]{2}{*}{ d_electro_IT } & & 0.115 & \\
\hline & & $(0.290)$ & \\
\hline \multirow[t]{2}{*}{ d_construc } & & 0.500 & \\
\hline & & $(0.678)$ & \\
\hline \multirow[t]{2}{*}{ d_wsale_retail } & & 0.0255 & \\
\hline & & $(0.301)$ & \\
\hline \multirow[t]{2}{*}{ d_hotel_trans } & & -1.394 & \\
\hline & & $(0.900)$ & \\
\hline \multirow[t]{2}{*}{ Constant } & $-1.386^{* * *}$ & $-1.294 * * *$ & $-1.305^{* * *}$ \\
\hline & $(0.110)$ & $(0.117)$ & $(0.113)$ \\
\hline Observations & 7,526 & 7,525 & 7,526 \\
\hline Log likelihood & -3823 & -3814 & -3817 \\
\hline Pseudo R2 & 0.187 & 0.188 & 0.188 \\
\hline
\end{tabular}

$* * * \mathrm{p}<0.01, * * \mathrm{p}<0.05, * \mathrm{p}<0.1$

Source: own calculations. 
Firstly, we discuss the benchmark results presented in column (1) for the standard firm characteristics, but without the sectoral effects. Our estimation results reveal that all the variables are statistically significant at the 1 percent level. The estimated parameter on the key explanatory variable - the EMU membership displays a positive sign and is statistically significant. This means that firms from the Eurozone countries presumably face the lower transaction costs in entering the markets in other Eurozone countries and reveal a higher propensity to export. In addition to this, the estimated parameter on the EU membership also displays a positive sign and is statistically significant. However, the magnitude of the estimated parameter on the EMU variable is almost twice as large as the one on the EU variable. This means that from the perspective of the CEE countries, the accession to the EU increases the propensity to export of their firms and the accession to the Eurozone generates an additional increase in the extensive margin of exports.

The signs of the estimated parameters for our control variables are in line with expectations and results from other empirical studies based on the Melitz (2003) model. In particular, the level of labor productivity is positively related to the probability of exporting. Moreover, the level of R\&D spending and proportion of workers with university degrees are positively related to the probability of exporting. Finally, the probability of exporting increases with the firm's size, foreign ownership.

In column (2) of Table 3, we control for sector specific effects. In this case, the estimated parameter on the EMU variable remains positive and statistically significant at the 1 percent level, and its magnitude does not change much compared to the baseline estimation. Similarly, the inclusion of the sector specific variables does not affect the estimates of the coefficients on all other variables. The only statistically significant sectoral variable was the dummy variable for the food producing sector, which displayed a negative sign. Therefore, in the last specification presented in column (3) we omitted all sectoral variables that have not been statistically significant. This change did not affect our previous conclusions concerning the role of the common currency. Thus, it seems that our results are robust with respect to the time and sector specific effects.

\section{Conclusions}

In this paper, we investigated the ex post effects of the accession to the Eurozone by two Central European countries that adopted the euro: Slovenia and Slovakia on the export activity of their firms. In contrast to the previous studies that were based on the gravity model and the aggregate trade flows, we used the extended Melitz (2003) model and the firm-level data. The key 
explanatory variable in this model was the level of productivity. In addition to this, we also controlled for other factors that may affect export activity, such as the level of innovation, the stock of human capital, the foreign ownership, and the size of the firm.

Our estimation results demonstrated that the EMU membership positively affects the probability of exporting. This means that firms from Slovenia and Slovakia after the accession to the Eurozone indeed reveal a higher propensity to export. Moreover, the EU membership is also positively related to the probability of exporting. The estimated parameters on our control variables, such as productivity, the size of the firm, and the stock of human capital, were in line with the results of previous empirical studies based on the Melitz (2003) model. Finally, we controlled for both individual time and sectoral effects.

The results concerning the significance of the EMU membership are different from the previous estimations based on the gravity model and aggregate trade flows. However, these two sets of empirical results do not have to be mutually exclusive. The results based on the aggregate data may not properly reflect microeconomic gains as the value of aggregate exports may be affected by the increased competition resulting in the compression of prices. In addition, the estimations based on the aggregate data can mask gains resulting from changes in extensive and intensive margins.

However, our results based on the firm-level data should also be treated with caution, as we were unable to use panel data and we estimated only the equivalent of the extensive margin effects. The more accurate analysis of both the extensive and intensive margin effects requires a more detailed disaggregated data on the geographical structure of exports. Another potentially fruitful extension of our analysis could be the inclusion of country characteristics.

\section{References}

Aristovnik A., Meze M. (2009), The Economic and Monetary Union's Effect on (International) Trade: The Case of Slovenia Before Euro Adoption, "MPRA Paper" No. 17445,

Baldwin R.E. Skudelny F., Taglioni D. (2005), Trade effects of the euro - evidence from sectoral data, Working Paper Series 446, European Central Bank.

Baldwin R.E. (2006), The euro's trade effect, ECB Working Paper N.594.

Barr D., Breedon F., Miles D. (2003), Life on the outside: Economic conditions and prospects outside euroland, "Economic Policy", Vol. 18, No. 37.

Belke A., Spies J. (2008), Enlarging EMU to the East: What Effects on Trade?, "Empirica", Vol. 35. 
Berger H, and Nitsch, V. (2008), Zooming Out: The Trade Effect of the Euro in Historical Perspective, "Journal of International Money and Finance", Vol. 27.

Berman N., Martin P., Mayer T. (2009), How do different exporters react to the exchange rate changes? Theory, empirics and aggregate implications, EFIGE working paper 20.

Brouwer J., Paap P., Viaene J-M. (2008), The Trade and FDI Effects of EMU Enlargement, "Journal of International Money and Finance", Vol. 27.

Cieślik A., Michałek J.J., Michałek A. (2012a), Determinanty działalności eksportowej polskich firm, ,Gospodarka Narodowa”, Vol. LXXX/XXI, No. 7-8.

Cieślik A., Michałek J.J., Michałek A. (2012b), Export activity in Visegrad-4 countries: Firm-level investigation, "Ekonomia”, No. 30.

Cieślik A., Michałek J.J., Mycielski J. (2009), Prognoza skutków handlowych przystapienia do Europejskiej Unii Monetarnej dla Polski przy użyciu uogólnionego modelu grawitacyjnego, „Bank i Kredyt”, No. 40 (1).

Cieślik A., Michałek J.J., Mycielski J. (2012a), Measuring the trade effects of the euro in Central and Eastern Europe, "The Journal of International Trade \& Economic Development", Vol. 21, No. 1.

Cieślik A., Michałek J.J., Mycielski J. (2012b), Euro and Trade Flows in Central Europe, "Equilibrium, Quarterly Journal of Economics and Economic Policy", Vol. 7, No. 3.

Cieślik A., Michałek J.J., Mycielski J. (2012c), Consequences of the euro adoption by Central and Eastern European (CEE) countries for their trade flows, National Bank of Poland Working Paper No. 118.

European Firms in a Global Economy: EFIGE (2010), The Global Operations of European Firms. The second EFIGE Policy Report, Bruegel.

Feuerstein S., Grimm O. (2007), The Enlargement of the European Monetary Union, "Bank i kredyt", No. 2.

Fontagne L., Mayer T., Ottaviano G.I.P. (2009), Of markets, products and prices. The effects of the euro on European firms, Breugel Blueprint Series, No 8.

Krugman P. (1980), Scale economies, product differentiation and the pattern of trade, "American Economic Review", Vol. 70, No. 5.

Melitz M. (2003), The impact of trade in intra-industry reallocations and aggregate industry productivity, "Econometrica”, Vol. 71, No. 6.

Fidrmuc J., Korhonen I. (2006), Meta-Analysis Of The Business Cycle Correlation Between The Euro Area And The CEECs, Cesifo Working Paper No. 1693.

Flam H., Nordstrom H. (2003), Trade Volume Effects of the Euro: Aggregate and Sector Estimates, Institute for International Economic Studies, unpublished.

Frankel J. (2008), Should Eastern European Countries join the Euro? The review and update of trade estimates of Endogenous OCA criteria, Research Working Paper, 08-059, J.F. Kennedy School of Government, Harvard University. 
Klučka, J., Strelcová S., Leláková E. (2009), EURO in the Slovak Republic, "Scientific Papers Of The University Of Pardubice Series D Faculty of Economics and Administration", Vol. 14.

Maliszewska M.A. (2004), New Member States Trading Potential Following EMU Accession: A Gravity Approach, "Studies and Analyses", No. 286, CASE - Center for Social and Economic Research.

Micco A. Stein, E., Ordonez, G. (2003), The Currency Union Effect on Trade: Early Evidence from EMU, "Economic Policy", Vol. 18.

Rose A. (2000), One Money, One Market: Estimating the Effect of Common Currencies on Trade, "Economic Policy", Vol. 15

Rose A. (2001), Currency Unions and Trade: The Effect is Large, "Economic Policy", Vol. 16.

Sivak R. (2011), Experience of Slovakia of accession to the Eurozone [in:] Lis S. (ed.), Kontrowersje wokól akcesji Polski do Unii Gospodarczej $i$ Walutowej, Wydawnictwo Uniwersytetu Krakowskiego, Kraków. 